\title{
The Effectiveness of Gojek's Product Placement in Keluarga Cemara Movie towards Purchase Intention
}

\author{
Dhea Anggeliana ${ }^{a}$, Muhammad Gunawan Alif ${ }^{b}$, Christian Haposan Pangaribuan ${ }^{\mathrm{c}}$ \\ a, b, c Sampoerna University, Jakarta, Indonesia
}

\begin{abstract}
Objective - This study explores the influence of product placement towards purchase intention while assessing the effectiveness of the ad determined by aspects of prominence, celebrity endorsement, modality, attitude towards movie and attitude towards brand.

Methodology - This type of research was a quantitative method using associative research approach and measured by regression method. The distribution of questionnaires was a non-probability with simple random sampling. The survey was conducted to 184 respondents in Jakarta, Indonesia, in May 2019.

Findings - The research found that modality does have a direct and significant effect on attitude towards the movie, attitude towards the brand, and purchase intention. We also find that celebrity endorsement has an impact on attitude towards the brand and purchase intention, not on attitude towards the movie. Prominence does not seem to have any relationship with all dependent variables.

Novelty - Although research has investigated product/brand placement, we extend the literature by investigating modality, prominence, and celebrity endorsement.

Keywords: Product Placement; Modality; Celebrity Endorsement; Prominence

JEL Classification: M30, M31, M37

Article info: Received 2 March 2021; Revised 12 April 2021; Accepted 17 May 2021

Article Correspondence: christian.pangaribuan@sampoernauniversity.ac.id

Recommended Citation: Anggeliana, D., Alif, M. G., \& Pangaribuan, C. H. (2021). The Effectiveness of Gojek's Product Placement in Keluarga Cemara Movie towards Purchase Intention. Journal of Business, Management, and Social Studies, 1(1), 58-68.
\end{abstract}

\section{INTRODUCTION}

Traditional marketing is believed to have lost its effectiveness in stealing the audience's attention to the product advertised (Tarik \& Adnan, 2018). To market their product and services, companies are trying hard to captivate the minds of the public more effectively and efficiently, while trying to answer the question of "to what extent have marketers been able to successfully reach their customers?" (Nagar, 2016). The cost of advertising a product on TV is costly while the quantifiability of the viewing audience is not well measurable due to the possibility of changing the channels when the advertisement appears (Goldfarb \& Tucker, 2011).

The emergent of product placement started along with the birth of motion picture in the mid-1890s (Singhal et al., 2015). Product placement refers to a way to improve the promotion of products or services by displaying them with the impression that the existence of the products seems to be part of the story of films and television shows (Belch \& Belch, 2015). Solomon and English (1994) stated that product placement is the advertising mechanism of inserting products with "naturally occurring" in a movie. However, in this study, the authors only focus in analyzing the effectiveness of product placement in a movie for its perception as a medium that can reach all levels of society extensively. Thus, this study explores the influence of product placement towards purchase intention while assessing the effectiveness of the ad determined by aspects of prominence, celebrity endorsement, modality, attitude towards movie and attitude towards brand. 


\section{LITERATURE REVIEW}

\section{Product Placement}

Media communication is currently widely used to promote a product. In this case, many companies try to make advertising to introduce their product in the most effective way. One alternative promotion is placing the product on a film or as known as product placement. The strategy of product placement is not something new in marketing, and the definition has changed over the years. One of the initial understandings of product placement comes from Solomon and English (1994) stating that product placement is the advertising mechanism of inserting products with "naturally occurring" in a movie.

Product placement is a strategy to place brand names, products, product packaging, symbols, or logos in a film, television program, or other mobile media to increase the brand awareness of a product and stimulating the audiences to purchase a particular product. A product placement implementation will describe or insert in very natural consumption activities following the film's plot in a movie. In this case, when a brand in the film settled naturally, it will provide more exposure to the brand as if it is daily. As a result, the audiences will be easier to identify the information and gain the messages regarding the brand that is displayed in the movie. According to Stephen and Coote (2005), when a brand is shown in a realistic context (yet contrived), it will give a richer signal regarding the knowledge, image, and social information about the brand to the audiences forms of marketing communication medium.

Throughout the years, Balasubramanian et al. (2019) defined product placement as a form of paid inclusion promotion of a specific brand through audiovisual messages within mass media programs. They reflected the "hybrid" characteristic that integrates between advertising and publicity messages. In this case, the paid promotion concept through placement is more attractive to the brand sponsor because the "paid" ideas will allow them to control and drive the product messages in the movie. Additionally, product placement is more beneficial for the brand sponsors because they can incorporate their products to appear in the storyline of a movie. Therefore, the audiences will be difficult to miss or skip the product's messages (Kumar, 2017). Unlike conventional advertising media, such as advertising on television, the audiences cannot switch the channel, so potentially, the messages of the products will reach greater audiences.

Moreover, product placement can act as the future investment for the brand sponsors since the message will last longer in the movie (Singhal et al., 2015). Product placement in a movie can be an investment because the movie can be played repeatedly even though it has been several years ahead of the original release. Therefore, the message of products can infiltrate the audience's mind continually. Moreover, if the movie is released overseas, it will also reach more potential audiences to build brand awareness towards the product.

Product placement has several types and dimensions. According to Astous and Seguin (1998), there are several types of product placement: implicit product placement, integrated direct product placement, and non-integrated product placement. Implicit Product Placement is a type of product placement where a brand, product, or company appears in a movie or program without formally mentioned. The nature of this product placement is passive, so the brand name, $\log$, or name of the company appears without any explanation about the benefits or advantages. The second type is Integrated Explicit Product Placement, the type of product placement where a brand, product, or company is formally mentioned in a program. The nature of this product placement is active. In this type of product placement, the benefits or advantages are communicated well to the audiences. The last type of product placement is Non-Integrated Explicit Product Placement, a type of product placement where a brand, product, or company is formally mentioned in a program but not integrated in program content or movie. The sponsor's name appears at the beginning or middle and maybe at the end of the event or as part of the name.

According to Russell (2002), there are three dimensions of product placements: visual dimension, auditory dimension, and plot connection dimension. The visual dimension is the appearance of a brand on a screen, better known as a screen placement. The shape of this dimension has different levels depending on the number of views on the screen and the style of taking the camera or angle. The second dimension is the auditory dimension is when the brand is mentioned in dialogue or better known as a placement script. This dimension has varying degrees depending on the frequency of brand mention, emphasis in mentioning 
the brand, language style, intonation, placement in dialogue, and the actors who mention the brand. The last dimension is the Plot Connection Dimension (PCD), which is a combination of all dimensions of brand placement in the story of a film. High PCD will strengthen the theme of the story element. This placement dimension is most often done and said to be the most effective because it usually significantly impacts communicating a brand.

Those dimensional proposed by Russell (2002) can derive the company to carefully choose in what kind of dimension their brand would be shown to the customers through a certain movie. According to Shrum (2004), the brand that appeared in a certain movie or TV show is associated with various psychological processes that can influence the viewers and increase the brand awareness of its brand.

\section{Prominence}

Gupta and Lord (1998) defined prominence as making the product or brand in product placement highly visible by position, the virtue of size, or centrality to the action in the scene. In this research, the writers extend the determination of prominence in product placement as the brand's position is visually displayed in the movie by size from the brand exposure and the centrality of the brand to the action in the scene (plot scenario). In this study, the variable of prominence relevant to the theory of secondary brand association is in line with classical conditioning theory. Suppose the association of position, size of visibility, and the centrality of Gojek are continually exposed in the movie. In that case, it is assumed will affect the attitude towards the movie and the attitude towards the brand. In this study, the hypotheses of prominence showed below:

Hypothesis 1 (H1): Prominence of Gojek product placement has a significant influence on attitude towards Keluarga Cemara movie

Hypothesis 4 (H4): Prominence of Gojek product placement has a significant influence on attitude towards brand

Hypothesis 10 (H10): Prominence of Gojek product placement has a significant influence on Purchase Intention

\section{Celebrity Endorsement}

Celebrity endorsement can be defined as using a public figure, actors/actress, or entertainer, or someone that many people know to support the product/service being advertised (Sunita, 2017). In this study, the variable of celebrity endorsement relevant to the theory of secondary brand association that line with classical conditioning theory. When a brand used or stated by the familiar actors/actress in a movie as the product placement, it will create such a special bond between the brand and the viewers so that it can increase their attitude towards the brand, especially when the brand is new in the market (Kit \& P'ng, 2014). Sridevi (2012) also supported this theory that a product used or endorsed by the viewer's favorite celebrities could build such a valuable role in increasing brand awareness and enhancing the brand attitude. Therefore, the hypothesis of this is shown below:

Hypothesis 2 (H2): Celebrity Endorsement of Gojek product placement has a significant influence on attitude towards Keluarga Cemara movie

Hypothesis 5 (H5): Celebrity Endorsement of Gojek product placement has a significant influence on attitude towards brand

Hypothesis 11 (H11): Celebrity Endorsement of Gojek product placement has a significant influence on Purchase Intention 


\section{Modality}

Modality is the appearance of the brand as the product placement in the scene of the movie or the brand mentioned in the dialogue (Russell, 2002). In this study, modality is relevant to the dual coding theory. This theory assumed that the human mind consists of two separate subsystems: verbal subsystem and visual subsystem (Clark \& Paivio, 1991). When a brand is associated with verbal words and an image, the human brain will process both the information in each memorial system and connect it (Schunk, 2012). As a result, the viewer will be easier to remember the name of the brand, and it looks due to the more significant amount of memory traces. In the end, the memory obtained by the viewers will determine the brand attitude of the viewers that could lead to the purchase intention of the product. Therefore, the hypothesis of this is shown below:

Hypothesis 3 (H3): Modality of Gojek product placement has a significant influence on attitude towards Keluarga Cemara movie

Hypothesis 6(H6): Modality of Gojek product placement has a significant influence on attitude towards brand

Hypothesis 12 (H12): Modality of Gojek product placement has a significant influence on Purchase Intention

\section{Attitude towards a movie}

Attitude towards the movie is defined as the amount of affection or against the object (in this study, specifically in the movie) (Thurstone, 1931). In this case, prominence, celebrity endorsement, and modality are the variables that are assumed to influence the attitude towards the movie. According to the previous study, attitude towards movies will be relevant to secondary brand association theory (Keller, 2013). In this case, the brand placed in the movie associated with prominence, celebrity endorsement, and modality creates such a strong attraction for the viewers to like the movie. It is assumed that when someone wants the movie, they will tend to have a brand attitude of the product placement. Moreover, it also assumed that when someone pays attention to the movie, they will receive the exposure of the product placement mentioned in the movie to increase the purchase intention. The cognitive structure between all those variables on attitude towards film created two kinds of hypotheses that shown below:

Hypothesis 7 (H7): Attitude towards Keluarga Cemara movie has a significant influence on attitude towards the brand of Gojek's product placement

Hypothesis 8 (H8): Attitude towards Keluarga Cemara movie has a significant influence on purchase intention of Gojek's product placement

\section{Attitude towards the Brand}

According to Mitchel \& Olson (1981), attitude on an object is defined as an individual's evaluation of the object. According to the previous study, attitude towards brand will relevant with secondary brand association theory (Keller, 2013). In this case, the brand placed in the movie associated with prominence, celebrity endorsement, modality, and attitude towards movie creates such a substantial message transfer for the viewers to have the attitude towards the brand. Moreover, it is assumed when someone also likes or gives attention to the movie; it will increase the brand attitude of the placed product so that it can lead to the purchase intention. Therefore, the hypothesis is shown below:

H9 : Attitude towards brand of Gojek's product placement (BA) has a significant influence on purchase intention of Gojek's product placement. 


\section{Purchase Intention}

Purchase intention is defined as the willingness of consumer to purchase the product that associated with celebrity engagement to fulfill consumers' needs and wants (Hunter, 2010). In Pangaribuan and Fadlina's (2019) study, purchase intention is assessed by four dimensions: intention to learn, willingness to purchase with higher price, willingness to recommend, and tendency to buy. Individuals interested in an entity will have the strength or encouragement to do a series of behaviors to approach or get the object. According to Schiffman and Kanuk (2007), purchase intention can be triggered through external influences, awareness of needs, product introduction, and alternative evaluation that can lead to consumer buying interest. The product's opening through the movie can indirectly evaluate the effects in the product placement. All the theories mentioned above lead to drive each variable to influence another variable. When the brand's exposure happened continually and is supported with the attitude towards the movie and the positive attitude towards the brand, it will significantly affect the purchase intention.

\section{RESEARCH METHODOLOGY}

This study aims to know the role of relationships and the impact of prominence, celebrity endorsement, modality, attitude towards the movie, and brand attitude on purchase intention. The time of the study started from 1 May 2019 by choosing the respondents from students and workers who had watched a movie selected by the researcher as the research object, entitled Keluarga Cemara, which was released on 3 January 2019. The movie was adapted from a TV series entitled Keluarga Cemara, which tells about the simplicity and warmth of an exemplary family from 1996 to 2005. However, on the re-make of the Keluarga Cemara movie that aired in 2019, the story made it into a more modern tale. In the Keluarga Cemara movie that aired in theaters, one of the famous startup transportation company Gojek appeared to be one of the movie-makers sponsors. Many movie scenes in Keluarga Cemara movie show Gojek's product placements such as services, logo, and dialogues. Even Gojek's product placement in the Keluarga Cemara movie also contributed to changing the movie's storyline.

The study's data was collected by spreading the questionnaires in the form of a link through social media platforms including Facebook, Instagram, Line, LinkedIn, and WhatsApp. The authors also collected the data by direct approaching the potential respondents. In the end, the result of the questionnaires used as the primary data to construct this thesis. The respondents were chosen based on the criteria and category needed for this study. As stated in the previous part, the respondents must be from students and workers who had watched the Keluarga Cemara movie. The questionnaires are designed in the form of a Likert scale, a rooted scale of research to measure attitudes and opinions. Using the Likert scale method, the respondents asked to complete a questionnaire that required them to show their level of agreement related to a single 'latent' variable through several 'manifested' questions expressed in the questionnaire (Joshi et al., 2015). This study's questions or statements are referred to as the research variables explicitly determined by the writers. Likert scale was preferred to avoid developing pairs of dichotomous adjectives, and it is easy to understand by the respondents (McDaniel \& Gates, 2013).

\section{Population and Samples}

The locations of the study were based on the cities where Gojek's operation is available. The preferred respondents are those in the age range of 18-35 years old and have a good understanding about online transportation platforms.

Sampling is one of the methods in conducting research. The subset from the chosen sampling frame or entire population is taken to make an inference or generalize a people related to existing theory (Taherdoost, 2016). According to Taherdoost (2016), in non-probability sampling, clear rationale criteria of some cases to meet the research's aim. The type of the non-probability sampling chosen for this study is purposive or judgmental sampling. The non-probability sample will allow a particular setting applied in the selected correspondent to obtain the important information needed (Maxwell, 1996). Moreover, a 5\% confidence level for a sample size between 30 and 500 respondents is generally sufficient (Delice, 2010). 
According to Hair et al. (2010), the minimum sample size is obtained by requiring a minimum of five subjects per variable needed. In this study, the sample size gained from a total of 31 questions from the variables times with 5 subjects (30x5), and it results from having 150 people. Therefore, after considering several factors, this study decided to have a sample size of a minimum of 150 respondents. Table 1 shows all of the variables that will be analyzed in this study.

Table 1. Variable Operationalization

\begin{tabular}{|c|c|c|c|}
\hline Variable & Indicator & Definition & Scale \\
\hline $\begin{array}{l}\text { Prominence } \\
\text { (P) } \\
\text { Gupta \& Lord (1998) }\end{array}$ & $\begin{array}{l}\text { 1.The position of the } \\
\text { brand appears in the } \\
\text { movie } \\
\text { 2. Virtue of size } \\
\text { 3. Centrality of the brand } \\
\text { to the action in scene }\end{array}$ & $\begin{array}{l}\text { The effort of make the product or } \\
\text { brand in product placement is } \\
\text { highly visible by position, virtue } \\
\text { of size, or centrality to the action } \\
\text { in the scene. }\end{array}$ & $\begin{array}{l}\text { Likert Scale, 1-4 } \\
\text { points }\end{array}$ \\
\hline $\begin{array}{l}\text { Celebrity Endorsement } \\
\text { (CE) } \\
\text { Sunita, K. (2017) }\end{array}$ & $\begin{array}{l}\text { 1.Celebrities mention the } \\
\text { name of the brand in the } \\
\text { movie. } \\
\text { 2. Celebrities use the } \\
\text { product in the story line. } \\
\text { 3.Celebrities recommend } \\
\text { the brand in the movie. }\end{array}$ & $\begin{array}{l}\text { The use of a public figure, } \\
\text { actors/actress, or entertainer, or } \\
\text { someone that many people know } \\
\text { to support the product/service } \\
\text { being advertised. }\end{array}$ & $\begin{array}{l}\text { Likert Scale, 1-4 } \\
\text { Points }\end{array}$ \\
\hline $\begin{array}{l}\text { Modality } \\
\text { (M) } \\
\text { Russell (2002) }\end{array}$ & $\begin{array}{l}\text { 1. Visual } \\
\text { 2. Audio }\end{array}$ & $\begin{array}{l}\text { The appearance of the brand as } \\
\text { the product placement in the } \\
\text { scene or the brand that mentioned } \\
\text { in the dialogue. }\end{array}$ & $\begin{array}{l}\text { Likert Scale, 1-4 } \\
\text { Points }\end{array}$ \\
\hline $\begin{array}{l}\text { Attitude towards Movie } \\
\text { (AM) } \\
\text { Spears \& Singh (2004). }\end{array}$ & $\begin{array}{l}\text { 1.Good/Bad movie } \\
\text { 2.The movie is interesting } \\
\text { 3.The movie is } \\
\text { Recommended } \\
\text { 4.Planning to re-watch the } \\
\text { Movie }\end{array}$ & $\begin{array}{l}\text { The amount of affection or } \\
\text { against towards the object (in this } \\
\text { study specifically in the movie) }\end{array}$ & $\begin{array}{l}\text { Likert Scale, 1-4 } \\
\text { Points }\end{array}$ \\
\hline $\begin{array}{l}\text { Attitude to the brand } \\
\text { (BA) } \\
\text { Batra et al. (1990) }\end{array}$ & $\begin{array}{l}\text { 1.Bad/Good brand } \\
\text { 2.Unfovarable/Favorable } \\
\text { 3.Disagreeable/Agreeable } \\
\text { 4. Unpleasent/Pleasant }\end{array}$ & $\begin{array}{l}\text { According to Mitchel \& } \\
\text { Olson (1981) defined attitude on a } \\
\text { brand is an individual's } \\
\text { evaluation towards the brand. }\end{array}$ & $\begin{array}{l}\text { Likert Scale, 1-4 } \\
\text { Points }\end{array}$ \\
\hline $\begin{array}{l}\text { Purchase intention } \\
\text { (PI) } \\
\text { Dodds et al. (1991) }\end{array}$ & $\begin{array}{l}\text { 1.The likelihood of } \\
\text { purchasing this product } \\
\text { 2.The probability that I } \\
\text { would consider buying the } \\
\text { product } \\
\text { 3. My willingness to buy } \\
\text { the product }\end{array}$ & $\begin{array}{l}\text { Purchase intention defined as the } \\
\text { state of mental of consumers that } \\
\text { reflects the plan to purchase a } \\
\text { product on certain brands or } \\
\text { objects. }\end{array}$ & $\begin{array}{l}\text { Likert Scale, 1-4 } \\
\text { points }\end{array}$ \\
\hline
\end{tabular}

\section{FINDINGS AND RESULT}

In conducting the validity test, Kaiser- Mayer-Olkin (KMO) statistic and anti-image correlation were used as the measurement criteria. According to Field (2009), KMO statistic value of 0.5 is barely acceptable or valid; value between 0.5 and 0.7 is considered acceptable; value of 0.7 and 0.8 is good; value between 0.8 and 0.9 or more is great. In conducting the reliability test, Cronbach's alpha was used as the measure to determine whether the scale is reliable or not. Field (2009) stated that the scale needs to have at least 0.7 value of Cronbach's $\alpha$. The value of 0.7-0.8 or more is the range in which the Cronbach's $\alpha$ value is acceptable or reliable. Otherwise, if the value is lower than 0.7 , it is considered unreliable. The summary of the validity and reliability of each questionnaire questions can be seen in Table 2 . All survey items are valid and reliable. Therefore, they are eligible to be used for further analysis. 
Table 2. Validity and Reliability

\begin{tabular}{|c|c|c|c|c|}
\hline Variable & Alpha & KMO & Items & Coefficient \\
\hline \multirow{3}{*}{ Prominence (PO) } & \multirow{3}{*}{0.647} & \multirow{3}{*}{0.655} & PO1 & 0.645 \\
\hline & & & $\mathrm{PO} 2$ & 0.629 \\
\hline & & & PO3 & 0.706 \\
\hline \multirow{3}{*}{$\begin{array}{l}\text { Celebrity Endorsement } \\
\text { (CE) }\end{array}$} & \multirow{3}{*}{0.663} & \multirow{3}{*}{0.580} & CE1 & 0.587 \\
\hline & & & CE2 & 0.553 \\
\hline & & & CE3 & 0.630 \\
\hline \multirow[t]{2}{*}{ Modality (MO) } & \multirow{2}{*}{0.720} & \multirow{2}{*}{0.500} & MO1 & 0.500 \\
\hline & & & MO2 & 0.500 \\
\hline \multirow{4}{*}{ Attitude to Movie (AM) } & \multirow{4}{*}{0.713} & \multirow{4}{*}{0.665} & AM1 & 0.747 \\
\hline & & & AM2 & 0.624 \\
\hline & & & AM3 & 0.723 \\
\hline & & & AM4 & 0.645 \\
\hline \multirow{4}{*}{ Attitude to Brand (BA) } & \multirow{4}{*}{0.638} & \multirow{4}{*}{0.519} & BA1 & 0.521 \\
\hline & & & BA2 & 0.827 \\
\hline & & & BA3 & 0.219 \\
\hline & & & BA4 & 0.511 \\
\hline \multirow{3}{*}{ Purchase Intention (PI) } & \multirow{3}{*}{0.888} & \multirow{3}{*}{0.685} & PI1 & 0.676 \\
\hline & & & PI2 & 0.805 \\
\hline & & & $\mathrm{PI} 3$ & 0.624 \\
\hline
\end{tabular}

According to the survey collected (see Table 3), more than $90 \%$ have seen the movie Keluarga Cemara. In the age category, the majority of the respondents are from 18-25 years old (79.90\%), followed by $26-30$ $(17.90 \%)$, and $31-35(2.20 \%)$. Half of the respondents live in Jakarta $(50.00 \%)$. The gender of the respondents are mostly females $(64.10 \%)$ and education level is mostly high school graduates $(40.80 \%)$. In the category of cinema visit frequency, the leader is at least once a month at $54.90 \%$, followed by once every 4 months at $24.50 \%$, bi-weekly visit at $13.00 \%$, once every 6 months at $4.30 \%$, and weekly visit at $3.30 \%$. Most of the respondents' preferences in movie genre are action movies $(25.50 \%)$, followed by adventure (18.50\%), horror (13.60\%), comedy (10.90\%), sci-fi (9.80\%), drama (9.20\%), family (8.20\%), and history $(4.30 \%)$. Most of the respondents' motivation to watch a movie is the storyline $(71.20 \%)$, followed by the reason of it being currently trending (12.5\%), lead actor/actress $(9.20 \%)$, and special effects of the film $(7.10 \%)$

Table 3. Demography of the Respondents

\begin{tabular}{|c|c|c|c|}
\hline \multicolumn{2}{|c|}{ Category } & $\mathbf{N}$ & $\%$ \\
\hline \multirow{2}{*}{ Seen the movie? } & Yes & 184 & 90.60 \\
\hline & No & 19 & 9.40 \\
\hline \multirow{10}{*}{ Residence } & Jakarta & 92 & 50.00 \\
\hline & Bogor & 13 & 7.10 \\
\hline & Depok & 19 & 10.30 \\
\hline & Bekasi & 12 & 6.50 \\
\hline & Bandung & 26 & 14.10 \\
\hline & Surabaya & 4 & 2.20 \\
\hline & Malang & 3 & 1.60 \\
\hline & Yogya & 10 & 5.40 \\
\hline & Solo & 4 & 2.20 \\
\hline & Semarang & 1 & 0.50 \\
\hline \multirow{2}{*}{ Gender } & Male & 66 & 35.90 \\
\hline & Female & 118 & 64.10 \\
\hline \multirow{3}{*}{ Age } & $18-25$ & 147 & 79.90 \\
\hline & $26-30$ & 33 & 17.90 \\
\hline & $31-35$ & 4 & 2.20 \\
\hline \multirow{3}{*}{ Education } & High School & 75 & 40.80 \\
\hline & Diploma & 39 & 21.20 \\
\hline & Bachelor & 70 & 38.00 \\
\hline
\end{tabular}




\begin{tabular}{lccc}
\hline & Students & 120 & 65.20 \\
Occupation & Employees & 51 & 27.70 \\
& Self-employed & 9 & 4.90 \\
& In between jobs & 4 & 2.20 \\
\hline \multirow{4}{*}{ Cinema Visit } & Weekly & 6 & 3.30 \\
Frequency & Bi-weekly & 24 & 13.00 \\
& Once a month & 101 & 54.90 \\
& Every 4 months & 45 & 24.50 \\
& Every 6 months & 8 & 4.30 \\
\hline \multirow{4}{*}{ Movie Genre } & Action & 47 & 25.50 \\
Preference & Adventure & 34 & 18.50 \\
& Drama & 17 & 9.20 \\
& Comedy & 20 & 10.90 \\
& Family & 15 & 8.20 \\
& History & 8 & 4.30 \\
Reasons to watch & Horror & 25 & 13.60 \\
a movie & Sci-Fi & 18 & 9.80 \\
& Lead actor/actress & 17 & 9.20 \\
& Special effects & 13 & 7.10 \\
& Storyline & 131 & 71.20 \\
& Currently trending & 23 & 12.50 \\
\hline
\end{tabular}

The linear regression was conducted through SPSS and the model summary of each multiple regression was generated, including the multiple $\mathrm{R}(\mathrm{R})$ which is the coefficient of determination. The $\mathrm{R}$ illustrates the strength of the overall linear relationship which is the greater $\mathrm{R}$ is the better. Table 4 shows that the multiple $\mathrm{R}(\mathrm{R})$ in Model 1 is 0.466 , indicating a positive value but not that strongly correlated as it is $>0.1$. In comparison, models 2,3 , and 4 , the results indicate strength influence between independent variables and the dependent variable.

Table 4. Multiregression Test

\begin{tabular}{lrrll}
\hline Model & $\mathbf{R}$ & $\mathbf{R}^{\mathbf{2}}$ & \multicolumn{1}{c}{ Adjusted R $^{2}$} & Std. Error \\
\hline 1 & 0.466 & 0.217 & 0.204 & 0.06122 \\
2 & 0.806 & 0.650 & 0.642 & 0.05027 \\
3 & 0.878 & 0.770 & 0.768 & 0.06714 \\
4 & 0.896 & 0.802 & 0.799 & 0.06249 \\
\hline
\end{tabular}

Table 5. Coefficients

\begin{tabular}{llccccc}
\hline \multirow{2}{*}{1} & Model & B & Std. Error & Beta & t & Sig. \\
\cline { 2 - 7 } & (Constant) & 0.978 & 0.108 & & 9.082 & 0.000 \\
& AVPO & 0.008 & 0.008 & 0.064 & 0.964 & 0.336 \\
& AVCE & -0.008 & 0.102 & -0.009 & -0.079 & 0.937 \\
& AVMO & 0.275 & 0.066 & 0.460 & 4.139 & 0.000 \\
\cline { 2 - 7 } 2 & (Constant) & 1.140 & 0.107 & & -1.316 & 0.190 \\
& AVPO & -0.007 & 0.007 & -0.043 & -0.961 & 0.338 \\
& AVCE & 0.595 & 0.084 & 0.526 & 7.104 & 0.000 \\
& AVMO & 0.294 & 0.057 & 0.128 & 4.649 & 0.001 \\
& AVAM & 0.383 & 0.061 & 0.313 & 6.259 & 0.000 \\
\hline \multirow{2}{*}{3} & (Constant) & -0.807 & 0.112 & & -7.234 & 0.000 \\
& AVAM & 0.541 & 0.087 & 0.266 & 6.199 & 0.000 \\
& AVBA & 1.161 & 0.071 & 0.700 & 16.295 & 0.000 \\
& (Constant) & -0.838 & 0.110 & & -0.7631 & 0.000 \\
& AVPO & -0.004 & 0.008 & -0.017 & -0.497 & 0.620 \\
& AVCE & 1.190 & 0.104 & 0.635 & 11.425 & 0.000 \\
& AVMO & 0.369 & 0.068 & 0.304 & 5.444 & 0.000 \\
\hline
\end{tabular}


In Table 5, that the P-value (Sig.) of AVPO is 0.336 in which higher than 5\% of significance level. Under this circumstences, $\mathrm{Ha}$ is rejected since the P-value $>\alpha$. Therefore, AVPO has no significant influence towards Attitude. Thus, it can be concluded that $\mathrm{H} 1$ is not significant. From the discussion, we can also conclude that $\mathrm{H} 4, \mathrm{H} 10$, and $\mathrm{H} 2$ are not significant because their P-value (significance level) is higher than alpha. The other hypotheses (H3, H5, H6, H7, H8, and H9) show significant relationships.

The structural model of the research can be seen in Figure 1.

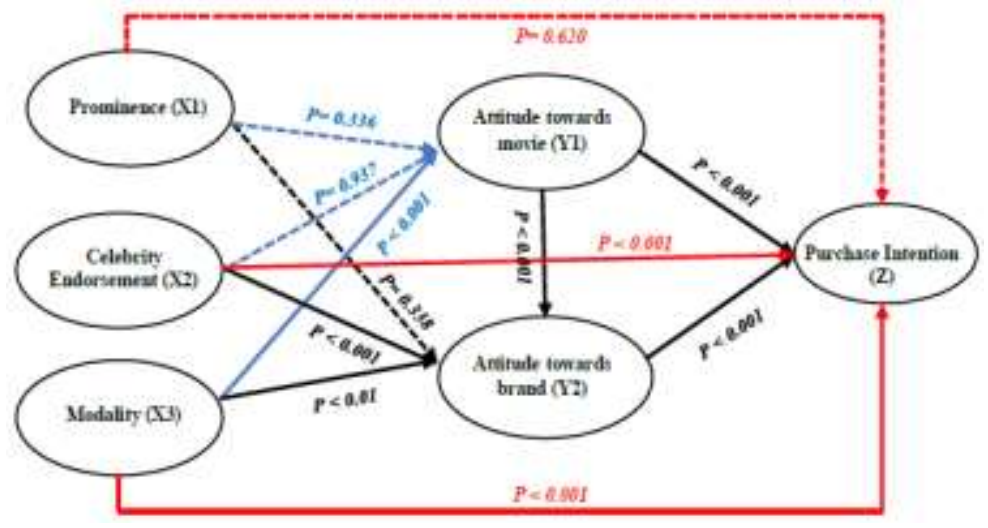

Figure 1. Research Model

\section{CONCLUSION}

In Model 1, two variables that are not significant with attitude towards movie are prominence and celebrity endorsement. However, the existence of modality in Gojek's product placement significantly influences audiences' attitudes towards the movie. This is in line with the past research conducted by Debatisse (2015), stated that the brand placed in the movie visually or mentioned in the audio have positively influence the interest of audiences towards the movie. Additionally, it is proven that modality completely gives evidence that the AIDA model can be used to understand the interest in attitude towards film could lead to the increasing purchase intention.

In Model 2, prominence also does not significantly affect the attitude towards Gojek's brand. From the four tested variables, the other three variables, which are celebrity endorsement, modality, and attitude towards movie, significantly influence the increasing brand attitude. The significance of celebrity endorsement value is in line with the previous study (Tangkuman \& Sarang, 2016). From a previous study, the celebrity endorsed by Samsung smartphone has positively increased the desire of people to buy the same phone. Based on the AIDA model, the celebrity endorsement impacts the desire of the audiences to purchase the same product as it used, mentioned, or recommended by the celebrity. The modality is also proved to have a significant influence on Gojek's brand attitude. In Ntsike's (2016) study, modality in the TV show advertisement has increased the awareness and interest of the audiences towards the brand of the car advertised. This finding means that modality in the product placement can increase the attention and the interest of the customers as proposed in the AIDA model. Based on the AIDA model, the awareness and interest toward a brand is expected to increase the purchase intention of the audience towards a brand.

Moreover, the product placement in TV series could help audiences memorize or be aware of the associated product (brand) (Karatas et al., 2012). The memory developed in the audience's mind is categorized as the first stage in the AIDA model, awareness. As a result, the audiences will be quickly aware of the associated brand in the product's placement every time they watch or hear the TV series.

In Model 3, two independent variables tested with one dependent variable resulted in the significant influence between attitude towards movie and brand attitude towards purchase intention. Based on the previous studies mentioned above, it is proved that more attitude towards movies could lead to more people 
having purchase intention towards a brand. In addition, the more people have a good attitude to a certain brand, the more they will have high purchase intention.

In Model 4, one variable that is not significant with purchase intention is prominence. The existence of celebrity endorsement in Gojek's product placement greatly influences Gojek's purchase intention. According to Tangkuman and Sarang (2016), celebrity endorsement has positively increased people's desire to buy the same phone. Based on the AIDA model, the celebrity endorsement has an impact to increase the desire of the audiences to purchase the same product as it used, mentioned, or recommended by the celebrity

Conclusively, based on the result finding of this research, Gojek's product placement in Keluarga Cemara movie does not significantly increase the purchase intention of the audiences towards Gojek's products. The result shows that only one variable significantly influence the attitude towards a movie which is celebrity endorsement, while three significant variables influence brand attitude, including celebrity endorsement, modality, and attitude towards the movie. This indicates that brand attitude has a stronger affecting the purchase intention compared to attitude towards movie. As a result, Gojek's product placement in the movie does not effectively influence the purchase intention without supported by other marketing strategies that can build the brand attitude. In this case, it will be difficult for a product placed in the movie to get high purchase intention if the product does not have a strong brand attitude at the beginning. In other words, product placement in the film is not recommended to be as tan advertisement media for the newly launched product.

Moreover, it is more suggested for the marketing department of Gojek to have product placement for their brand in the TV-Shows/Soap Opera rather than in the cinema. This is because there is the possibility of the product appear multiple times in the TV-Shows/Opera Soap since the programs will most likely be aired every day or more often. In this case, the intensity of the brand or product's exposure will be higher compare by placing the product in the cinema that is more likely to only appeared once or seasonal. Furthermore, based on the descriptive analysis, it is important to decide what movies should be chosen to place the product placement.

\section{REFERENCES}

Astous, A. \& Seguin, N. (1998). Consumer Reaction to Product Placement strategies in Television Sponsorship. European Journal of Marketing, 33(9), 887-889.

Balasubramanian, S. K., Pillai, D., Patwardhan, H., \& Zhao, T. (2019). Product Placement, in Communication, Patricia Moy (ed). Oxford University Press.

Batra, R. \& Stayman. (1990). The Role of Mood in Advertising Effectiveness. Journal of Consumer Research, 17(2), 203-214.

Belch, G. E. \& Belch, M. A. (2015). Advertising and Promotion: An Integrated Marketing Communications Perspective. McGraw-Hill.

Clark, J. M. \& Paivio, A. (1991). Dual Coding Theory and Education. Educational Psychology Review, 3(3), 149-210. doi:10.1007/BF01320076.

Delice, A. (2010). The Sampling Issue in Quantitative Method. Educational Sciences: Theory \& Practice, $10(4), 2-15$.

Doods et al. (1991). The Effects of Price, Brand, and Store Information on Buyer's Product Evaluation. Journal of Marketing Research, 28(3), 307-19. doi: 10.2307/3172866.

Field, A. (2009). Discovering Statistics Using SPSS, 4th ed. SAGE Publications.

Goldfarb, A. \& Tucker, C. (2011). Chapter 6 - Online advertising. Advances in Computers, 81, 289-315.

Gupta, B. P. \& Lord, K. R. (1998). Product Placement in Movies: The Effect of Prominence and Mode on Audience Recall. Journal of Current Issues \& Research in Advertising, 20(1), 48-52. Doi:10.1080/10641734.1998.10505076

Hair, J. F., Black, W. C., Babin, B. J., \& Anderson, R. E. (2010). Multivariate Data Analysis: Global Edition. Pearson Education Limited. 
Hunter, E. J. (2010). Celebrity entrepreneurship and celebrity endorsement: similarities, Differences and the effect of deeper engagement. Dissertation, Queensland Institute of Technology, Queensland, Australia

Karataş, N., Elverici, A., Cide, H. \& Yozgat, U. (2012). An Analysis of Product (Brand) Placement Techniques in Turkish Tv Series, Regarding Implicit Memory/Product (Brand) Recall and Knowledge Sharing. The Journal of Knowledge Economy \& Knowledge Management, 7(2), 146-150.

Keller, K. L. (2013). Strategic Brand Management - Building, Measuring, and Managing Brand Equity (4th ed.). Pearson Education, Inc.

Kit, L. C. \& P'ng, E. L. Q. (2014). The Effectiveness of Product Placement: The Influence of Product Placement towards Consumer Behavior of the Millennial Generation. International Journal of Social Science and Humanity, 4(2), 138-142.

Nagar, K. (2016). Consumer Response to Brand Placement in Movies: Investigating the Brand-Event Fit. Vikalpa, 41(2), 149-167.

Ntsike, M.S. (2016). The Impact of Product Placement On Consumer Involvement in The South African Automotive Industry. University of the Free State, 82-93.

Pangaribuan, C. H. \& Fadlina, R. (2019). Celebrity Entrepreneurship: How Communication Effectiveness Mediates the 5-D PATER Model and Purchase Intention. Journal of Marketing Thought, 6(1), 1-9.

Russell, C. (2002). Investigating the Effectiveness of Product Placements in Television Shows: The Role of Modality and Plot Connection Congruence on Brand Memory and Attitude. Journal of Consumer Research, 29(3), 306-318. doi:10.1086/344432

Russell, A. C \& Stern, B. B. (2006). Consumers, Characters, and Products: A Balance Model of Sitcom Product Placement Effects. Journal of Advertising, 35 (1), 7-21. Doi: 10.2753/JOA0091-3367350101.

Schunk, D. H. (2012). Learning Theories: An Educational Perspective (6 ${ }^{\text {th }}$ Ed.). Pearson

Shrum, L. J. (Ed.). (2004). The psychology of entertainment media: Blurring the lines between entertainment and persuasion. Lawrence Erlbaum Associates Publishers.

Singhal, A., Srivastava, C., \& Modi, S. (2015). Product Placement: More Effective than Traditional Advertising. International Journal of Management and Commerce Innovations, 3(2), 688-689.

Solomon, M. R. \& Englis, B. G. (1994). The Big Picture: Product Complementarily and Integrated Communications. Journal Advertising Research, 34(1), 57-63.

Spears, N \& Singh, S. (2004). Measuring Attitude Toward the Brand and Purchase Intentions. Journal of Current Issues and Research in Advertising, 26(2), 53-66. doi: 10.1080/10641734.2004.10505164.

Sridevi, J. (2012). Effectiveness of Celebrity Endorsement in Brand Recall and Brand Recognition. International Journal of Business, Economics and Management, 2(5), 203-209.

Stephen, A.T. \& Coote, L.V. (2005). Brands in Action: The Role of Brand Placements in Building Consumer-Brand Identification. American Marketing Association Conference Proceedings, 16, 28.

Sunita, K. (2017). Influence of Product Placements in Films and Television on consumers Brand Awareness. Archives of Business Research, 5(2), 163-171. doi: 10.14738/abr.52.2747

Tan, E. S. (2018). A psychology of the film. Palgrave Communications, 4(1), 1-20.

Tangkuman, R.S \& Saerang, D. P. E. (2016). The Effect of Product Placement in Movies and Celebrity Endorsement on Consumer Purchase Intention of Samsung Smartphone in Manado. Journal EMBA, 4(4), 1164-1172.

Tarik, Z. \& Adnan, S. (2018). Online vs Traditional; Marketing Challenge in the Telecom Market in Bosnia and Herzegovina. Economic Review: Journal of Economics and Business, 16(1), 45-57. 